University of New England

DUNE: DigitalUNE

8-15-2018

Prevalent Transoceanic Fall Migration By A 30-Gram Songbird, The Bobolink

Noah G. Perlut

Follow this and additional works at: https://dune.une.edu/env_facpubs

Part of the Ornithology Commons 


\title{
Prevalent transoceanic fall migration by a 30-gram songbird, the Bobolink
}

\author{
Noah G. Perlut \\ University of New England, Department of Environmental Studies, Biddeford, Maine, USA \\ nperlut@une.edu \\ Submitted April 6, 2018; Accepted June 6, 2018; Published August 15, 2018
}

\begin{abstract}
Three North American passerines are known to perform transoceanic flights during their fall migration, with openwater flights ranging in length from 1,700 to 3,400 km. However, little is known about within-population variation of these flights. From 2013 to 2017, I used geolocators to study variation in the fall migratory track of the Bobolink (Dolichonyx oryzivorus) from a population that bred in agricultural grasslands of Vermont, USA. Thirteen of seventeen birds took transoceanic flights during fall migration, ranging in length from 1,098 to 3,536 km (mean \pm SD $=1,969 \pm$ 640); five of these flights were nonstop from North to South America. Bobolinks initiated transoceanic flights between Nova Scotia, Canada, and the central coast of North Carolina, USA, an orthodromic distance of 2,500 km. Mean arrival to $12^{\circ}$ latitude in South America was October $17 \pm 17$ days (range: September 26-November 26). Neither sex, morphological measurements, nor age significantly explained variation in nonstop flight length.
\end{abstract}

Keywords: Bobolink, Dolichonyx oryzivorus, fall migration, geolocator, island stopover, transoceanic flight

\section{Migración de otoño transoceánica predominante de un ave canora de 30 gr, Dolichonyx oryzivorus RESUMEN}

Se conoce que tres paserinos de América del Norte realizan vuelos transoceánicos durante su migración de otoño, con vuelos sobre aguas abiertas con longitudes de entre 1,700 y 3,400 km. Sin embargo, poco se sabe sobre la variación intra-poblacional de estos vuelos. Desde 2013 a 2017, usé geo-localizadores para estudiar la variación en la ruta migratoria de otoño de Dolichonyx oryzivorus desde una población que cría en pastizales agrícolas de Vermont, EEUU. Trece de 17 aves realizaron vuelos transoceánicos durante la migración de otoño, con longitudes entre 1,098 y 3,536 km (media $\pm \mathrm{DE}=1969 \pm 640$ ); cinco de estos vuelos fueron sin parar desde América del Norte hasta América del Sur. D. oryzivorus inició los vuelos transoceánicos desde Nueva Escocia, Canadá y la costa central de Carolina del Norte, EEUU, una distancia ortodrómica de $2,500 \mathrm{~km}$. El arribo medio a la latitud $12^{\circ}$ en América del Sur fue Oct $17 \pm 17$ (rango: Sept 26 - Nov 26). El sexo, las medidas morfométricos o la edad no explicaron significativamente la variación en la longitud de los vuelos sin parada.

Palabras clave: Dolichonyx oryzivorus, geo-localizador, migración de otoño, parada en islas, vuelo transoceánico

\section{INTRODUCTION}

Tracking technology deployed on migratory songbirds is rapidly changing our understanding of their physiological and geographic limits. For example, miniaturized archival light-level geolocators have revealed dramatic, transoceanic crossings of 3 migratory songbird species. The 12-g Blackpoll Warbler (Setophaga striata) flies up to 2,770 km from northeastern North America, over the Atlantic Ocean, to the Greater Antilles (overwater distance scaled for body mass $233 \mathrm{~km} \mathrm{~g}^{-1}$; DeLuca et al. 2015). Likewise, the 13-g Connecticut Warbler (Oporornis agilis) flies 1,700-2,400 km from the eastern United States to Cuba or Hispaniola (McKinnon et al. 2017) during fall migration. At $25 \mathrm{~g}$, the Northern Wheatear (Oenanthe oenanthe) was tracked 3,400 km from the Canadian Arctic to the United Kingdom (overwater distance scaled for body mass $136 \mathrm{~km} \mathrm{~g}^{-1}$; Bairlein et al. 2012). This Northern Wheatear study demonstrated notably different migration strategies across that species' broad distribution, as birds from the western portion of their range instead took a land route to sub-Saharan Africa.

In contrast to Bairlein et al. (2012), Renfrew et al. (2013) examined variation in migration routes across the broad breeding distribution of the Bobolink (Dolichonyx oryzivorus), deploying geolocators on breeding birds in Oregon, Nebraska, and Vermont, USA. Persistent across the 3 breeding populations, all individuals $(n=15)$ used the same fall eastern migration corridor across the Caribbean Sea to Venezuela (Renfrew et al. 2013). While the Bobolinks in Renfrew et al. (2013) took an eastern fall migration route, it was not clear from that study whether birds exhibited any fall transoceanic flights, and that was not the focus of that study. Other studies using 
geolocators to describe fall migration of long-distance songbirds tracked both relatively similar (Stutchbury et al. 2009, Tøttrup et al. 2011, Schmaljohann et al. 2012) and different (Heckscher et al. 2011, Delmore et al. 2012) flight paths within and between populations. In cases where flight paths differed within populations, routes tended to vary across land and smaller (nonoceanic) bodies of water. Here, I used geolocators to examine within-population variation in autumn migration route and timing-specifically, to explore the prevalence and length of transoceanic flight relative to the age, sex, and body size of individual birds, including variation in stopover location and the timing of departure from the breeding grounds and arrival in South America.

\section{METHODS}

In May and June 2013-2016, I captured Bobolinks breeding in 2 hayfields located within the Champlain Valley $\left(44.39^{\circ} \mathrm{N}, 73.27^{\circ} \mathrm{W}\right)$, Vermont, USA, which contains 146,000 ha of managed grasslands (NASS 2010). I took standard morphological measurements (e.g., wing chord and body mass) and aged birds based on their capture history. I considered a newly banded adult bird to be a 2year-old bird for the purpose of this study (see Perlut and Strong 2016). This project was part of a long-term lifecycle study, where beginning in 2002, I attempted to capture and color-band all breeding Bobolinks on the study fields. I deployed light-level geolocators (0.65 g; Migrate Technology, Cambridge, UK) on 68 (36 female, 32 male) adults using a leg loop backpack harness made of Teflon tape and tied with super glue and liquid tape (20132014) or elastic cord (Stretch Magic, Pepperell Braiding Co., Pepperell, Massachusetts, USA) and crimps (20152016). I also banded 92 (36 female, 56 male) control birds, which did not wear geolocators.

I downloaded and formatted data in IntiProc v1.03 (Migrate Technology) and used the BAStag package within program R (R Core Team 2016) to estimate daily twilight times (Wotherspoon et al. 2016). I used FLightR (Rakhimberdiev and Saveliev 2016) to convert estimates of twilight times into estimates of longitude and latitude. FLightR uses a user-defined calibration period, via the template fit method (Ekstrom 2003, 2007), to model the relationship between the observed and expected light levels for each geolocator, as precision varies between units (Rakhimberdiev et al. 2015). For each bird's calibration periods, I used the day after the banding date through September 1 of the respective year and the day after the bird returned to the breeding grounds (mid-May to late May) through the recapture date. Including the second calibration period allowed me to employ the FLightR tag ageing model, which linearly accounts for increased opaqueness (i.e. decreased sensitivity) of the transparent shell of the light sensor over time.

I then used FLightR to map migration routes and identify the posterior distribution for the nonbreeding location (Rakhimberdiev et al. 2015). FLightR uses a hidden Markov chain model to estimate the location of migrating animals at dawn and dusk. Specifically, it uses a particle filter algorithm to combine a random walk movement model (with 2 states: sedentary or migrating), a hidden Markov model that probabilistically estimates unobserved animal locations, and a $50 \times 50 \mathrm{~km}$ grid optional user-defined spatial probability (Rakhimberdiev et al., 2015). This model allows users to define rules for grid cells based on whether they are over the ocean, where Bobolinks could not remain stationary over 2 twilights while over water. I ran FLightR with $10^{6}$ particles, the outlier routine turned on, and a 0.05 movement probability prior, including a movement direction prior of $180^{\circ}$ (i.e. due south; Renfrew et al. 2013). Within this model, Bobolinks could fly up to $1,500 \mathrm{~km}$ between sequential twilight events. I identified the onset of fall migration as the first movement that carried each bird south of its breeding grounds at least $45 \mathrm{~km}$ and not followed by any apparent northward movement (the default FLightR minimum distance for movement) and used the stationary.migration.summary function in FLightR, with a 5\% minimum movement probability, to identify stationary ( $\geq 2$ consecutive twilights) and movement periods throughout the fall migration for each bird. I combined stopover sites during migration that were in close proximity ( $<45 \mathrm{~km}$; e.g., Hahn et al. 2014, Jacobsen et al. 2017). I built a single, saturated linear regression model to test for associations between the nonstop distance of ocean water crossing and wing length, body mass, and age. Relatedly, I conducted a power analysis on wing length, body mass, and sex. There was sufficient power to detect differences (0.97) for both wing and mass, but power was low (0.75) for detecting differences between sexes. Results are presented as mean \pm SD unless otherwise stated.

\section{RESULTS}

From 2014 to 2017, I recovered 20 (34.5\%) geolocators from 8 females and 12 males, but 3 geolocators failed during deployment and contained no data. At the same time I recaptured or resighted 18 (19.5\%) control birds, including 4 females and 14 males. Thirteen of seventeen birds wearing geolocators ( 7 female, 10 male) took transoceanic flights lasting 1-5 days during fall migration, ranging from 1,098 to $3,536 \mathrm{~km}$ (1,969 \pm 640; Figure 1, Supplemental Material). Overwater flight distances were similar between sexes (female: $1,727 \pm 507 \mathrm{~km}$; male $2,137 \pm 693 \mathrm{~km}$; $t_{6,9}=$ $-1.33, P=0.102)$. Mean wing length was $91.9 \pm 4.7 \mathrm{~mm}$ (female: $87.6 \pm 1.87$; male: $95.3 \pm 2.64$ ); mean body mass at 


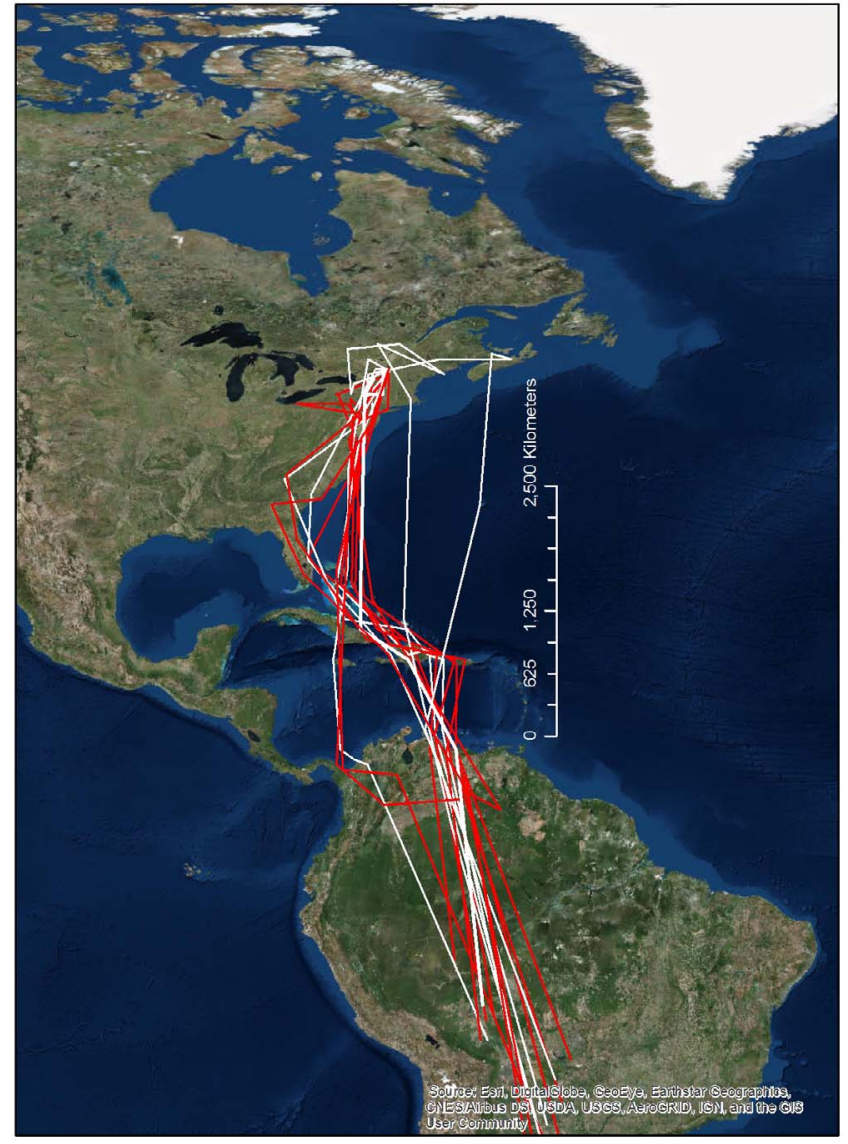

FIGURE 1. From a single breeding population in Vermont, 13 of 17 Bobolinks used transoceanic flights to cross the Atlantic Ocean and Caribbean Sea during fall migration. Each line represents a single male (red) or female (white) Bobolink flight path, as estimated by connecting consecutive twilight locations with an orthodromic line.

deployment was $31.8 \pm 3.07 \mathrm{~g}$ (female: $28.8 \pm 2.49$; male: $33.81 \pm 1.08)$; mean age at time of geolocator retrieval was 4.6 (range: 3-11, including 5 known-age birds originally banded as nestlings). None of the predictor variables was associated with overwater flight distance $(F=0.45, \mathrm{df}=4$ and $16, P=$ 0.76). Mean fall departure date from the breeding grounds was September $4 \pm 6.1$ days (range: August 26-September 14). The location of land departure varied from as far northeast as Nova Scotia and as far southwest as the central coast of North Carolina, an orthodromic distance of 2,500 $\mathrm{km}$. Of the 13 Bobolinks who took oceanic flights, 9 (69\%) departed from between the Delmarva Peninsula and coastal North Carolina, USA. Some Bobolinks may have stopped on Bermuda (1), Bahamas (3), Turks and Caicos (1), Cuba (3), Dominican Republic (5), and Puerto Rico (3), including multiple island stops by some individuals; however, given the error associated with geolocator data (see Appendix Figure 4), stopover on these exact islands should be interpreted with caution; 5 flew nonstop between North and South America.

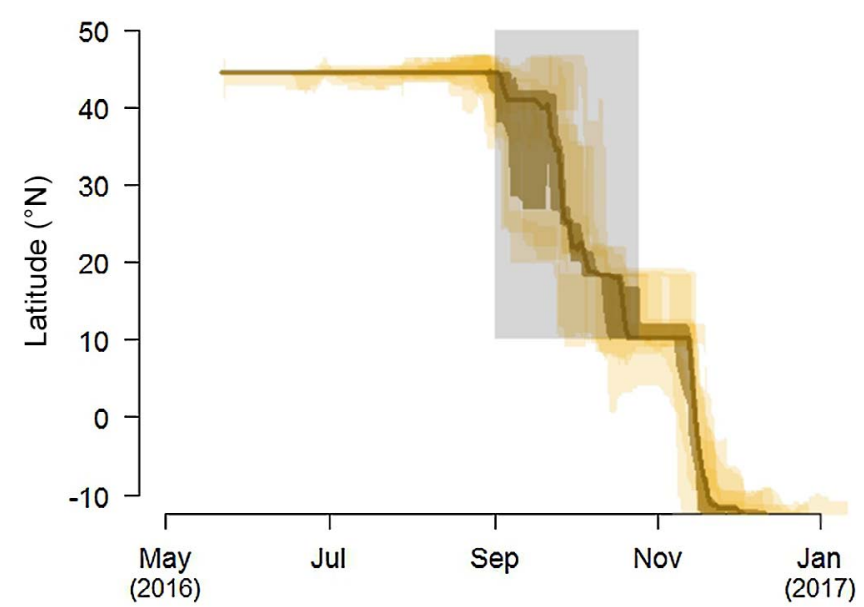

FIGURE 2. During Bobolinks' fall migration to northern South America (gray box), mean arrival to $12^{\circ}$ latitude in South America was October $17 \pm 17$ days. The dark line is the median latitude for that particular date, while the shaded area is the interquartile range.

All 17 Bobolinks converged in the same region of northern Venezuela and eastern Columbia (Figure 1). Mean arrival to $12^{\circ} \mathrm{S}$ latitude in South America was October $17 \pm 17$ days (range: September 26-November 26; Figure 2). Nonetheless, by mid-November, the population showed little variation in mean total migration length between Vermont and $12^{\circ} \mathrm{S}$ (Figure 3).

\section{DISCUSSION}

Bobolinks breeding in Vermont predominantly used transoceanic flights during fall migration. This project is the first to examine variation in transoceanic flights by

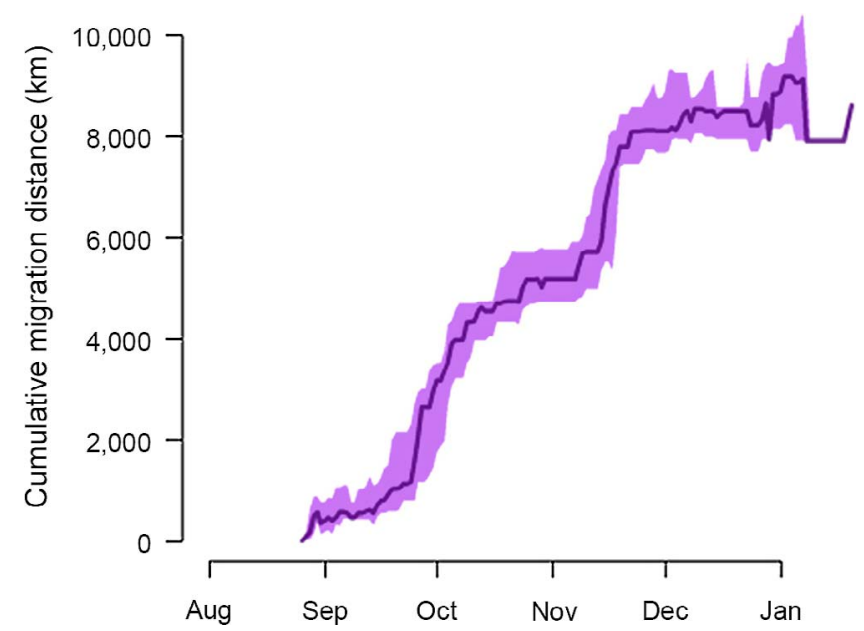

FIGURE 3. Cumulative migration distance flown by 17 Bobolinks during fall migration. The dark line is the median distance for that particular date, while the shaded area is the interquartile range. 
songbirds from a single breeding population-as the 3 other studies all had sample sizes of 4 or 5 individuals (Bairlein et al. 2012, DeLuca et al. 2015, McKinnon et al. 2017). Furthermore, this is the first known passerine to fly nonstop from North to South America over the Caribbean Sea, as both Blackpoll and Connecticut warblers made island stopovers (DeLuca et al. 2015, McKinnon et al. 2017); however, Bobolinks weighed $\sim 32 \mathrm{~g}$, notably larger than the other songbird species known to fly transoceanic flights, and their larger body mass may help facilitate longer flights. Indeed, many shorebirds, which weigh 2-4 times as much as Bobolinks, are known to have $>4,000 \mathrm{~km}$ nonstop flights (reviewed in Hedenström 2010). Why some birds choose long flights while other conspecifics choose stepping-stone flights is poorly understood. The "selfish herd" hypothesis potentially explains Bobolink long flights, where birds may deploy a "catch-up" strategy. Birds departing later could potentially use this faster, more efficient transoceanic flight to arrive in Venezuela more quickly, effectively catching up to any birds that had left earlier and taken a slower, overland route. Bobolinks from across North America have a synchronized arrival to Venezuela (Renfrew et al. 2013), where they likely join into large flocks; however, arrival dates in this study were asynchronous, spanning September 26-November 26. Their southward migration from Venezuela follows phenological change in the southern hemisphere. Therefore, this period in Venezuela could be a critical place where birds both refuel and share information, thereby increasing survival.

None of the predictor variables-sex, age, wing length, body mass-explained variation in oceanic crossing distance. Corman et al. (2014) suggested that the presence (or absence) of an ecological barrier (e.g., Caribbean Sea), rather than the distance itself, drives selection for traits that favor low flight costs (pointedness of wing tips). While the Atlantic Ocean and Caribbean Sea are large ecological barriers, I did not identify any within-population variation that supported wing length as a variable that defined the open ocean flight length. Age is known to affect migration timing and trajectory (Thorup et al. 2003) - but here, age did not explain variation in flight length. In this study, $76 \%$ of the birds undertook transoceanic flights, and $26 \%$ crossed the Caribbean Sea without stopping, which suggests that selection for long nonstop flights is strong in this species. Of course, this analysis does not include geolocator data from birds that failed to successfully complete transoceanic flights. The next step is to understand how these flights-along with other life-cycle components like wintering location and spring migration-interact in explaining variation in fitness on the breeding grounds. Likewise, these birds may only hint at the nonstop flight capabilities by Bobolinks-this species is known to stop on Galapagos during fall migration (Perlut and Renfrew 2016) and while we do not yet know the migration route or breeding grounds of those birds, if they depart from southern California, their nonstop flight could exceed $5,000 \mathrm{~km}$.

\section{ACKNOWLEDGMENTS}

Thanks to J. Hill for editorial comments on this manuscript and help with data analysis. Many thanks to J. Cava, E. White, Green Mountain Audubon, and the armies of research assistants who helped collect field data. Thanks to Shelburne Farms, S. Dixon, and the many private landowners who granted us access to their property.

Funding statement: This work was funded by TogetherGreen by Audubon, the Eppley Foundation for Research, Zero Gravity Craft Brewing, Oakhurst Dairy, D. Galipeau, and The University of New England.

Ethics statement: Followed IACUC permit and all bird banding permit requirements (federal and state).

\section{LITERATURE CITED}

Bairlein, F., D. R. Norris, R. Nagel, M. Bulte, C. C. Voigt, J. W. Fox, D. J. T. Hussell, and H. Schmaljohann (2012). Cross-hemisphere migration of a $25 \mathrm{~g}$ songbird. Biology Letters 8:505-507.

Corman, A-M., F. Bairlein, and H. Schmaljohann (2014). The nature of the migration route shapes physiological traits and aerodynamic properties in a migratory songbird. Behavioral Ecology and Sociobiology 68:391-402.

Delmore, K. E., J. W. Fox, and D. E. Irwin (2012). Dramatic intraspecific differences in migratory routes, stopover sites and wintering areas, revealed using light-level geolocators. Proceedings of the Royal Society of London, Series B 279: 4582-4589.

DeLuca, W. V., B. K. Woodworth, C. C. Rimmer, P. P. Marra, P. D. Taylor, K. P. McFarland, S. A. Mackenzie, and D. R. Norris (2015). Transoceanic migration by a $12 \mathrm{~g}$ songbird. Biology Letters 11:20141045.

Ekstrom, P. A. (2003). An advance in geolocation by light. Memoirs of the National Institute of Polar Research Special Issue 58:210-226.

Ekstrom, P. A. (2007). Error measures for template-fit geolocation based on light. Deep Sea Research Part II: Tropical Studies in Oceanography 54:392-403.

Hahn, S., T. Emmenegger, S. Lisovski, V. Amrhein, P. Zehtindjiev, and F. Liechti (2014). Variable detours in long-distance migration across ecological barriers and their relation to habitat availability at ground. Ecology and Evolution 4:41504160.

Heckscher, C. M., S. M. Taylor, J. W. Fox, and V. Afanasyev (2011). Veery (Catharus fuscescens) wintering locations, migratory connectivity, and a revision of its winter range using geolocator technology. The Auk 128:531-542.

Hedenström, A. (2010). Extreme endurance migration: What is the limit to non-stop flight? PLOS Biology 8:e1000362.

Jacobsen, L. B., N. O. Jensen, M. Willemoes, L. Hansen, M. Desholm, A. D. Fox, A. P. Tøttrup, and K. Thorup (2017). Annual spatiotemporal migration schedules in three larger 
insectivorous birds: European nightjar, common swift and common cuckoo. Animal Biotelemetry 5:4.

McKinnon, E. A., C. Artuso, and O. P. Love (2017). The mystery of the missing warbler. Ecology 98:1970-1972.

[NASS] National Agricultural Statistics Service (2010). The Census of Agriculture. U.S. Department of Agriculture, Washington, DC. http://www.agcensus.usda.gov/

Perlut, N. G., and R. B. Renfrew (2016). Bobolink autumn migration stopover on Galapagos. Wilson Journal of Ornithology 128:935-938.

Perlut, N. G., and A. M. Strong (2016). Comparative analysis of factors associated with first-year survival in two species of migratory songbirds. Journal of Avian Biology 47:858-864.

R Core Team (2016). R: A language and environment for statistical computing. Version 3.4. R Foundation for Statistical Computing, Vienna, Austria.

Rakhimberdiev, E., D. W. Winkler, E. Bridge, N. E. Seavy, D. Sheldon, T. Piersma, and A. Saveliev (2015). A hidden Markov model for reconstructing animal paths from solar geolocation loggers using templates for light intensity. Movement Ecology 3:25.

Rakhimberdiev, E., and A. Saveliev (2016). FLightR: SSM for solar geolocation. R package version 0.4.6. http://github.com/ eldarrak/FLightR

Renfrew, R. B., D. Kim, N. G. Perlut, J. Fox, and P. P. Marra (2013). Phenological matching across hemispheres in a long- distance migratory bird. Diversity and Distributions 19: 1008-1019.

Schmaljohann, H., J. W. Fox, and F. Bairlein (2012). Phenotypic response to environmental cues, orientation and migration costs in songbirds flying halfway around the world. Animal Behaviour 84:623-640.

Stutchbury, B. J. M., S. A. Tarof, T. Done, E. Gow, P. M. Kramer, J. Tautin, J. W. Fox, and V. Afanasyev (2009). Tracking longdistance songbird migration by using geolocators. Science 323:896.

Thorup, K., T. Alerstam, M. Hake, and N. Kjellén (2003). Bird orientation: Compensation for wind drift in migrating raptors is age dependent. Proceedings of the Royal Society of London, Series B 270:S8-S11.

Tøttrup, A. P, R. H. G. Klaassen, R. Strandberg, K. Thorup, M. Willemoes Kristensen, P. Søgaard Jørgensen, J. Fox, V. Afanasyev, C. Rahbek, and T. Alerstam (2011). The annual cycle of a trans-equatorial Eurasian-African passerine migrant: Different spatio-temporal strategies for autumn and spring migration. Proceedings of the Royal Society of London B 282:1-9.

Wotherspoon, S., M. Sumner, and S. Lisovski (2016). BAStag: Basic data processing for light based geolocation archival tags. Version 0.1.3. 


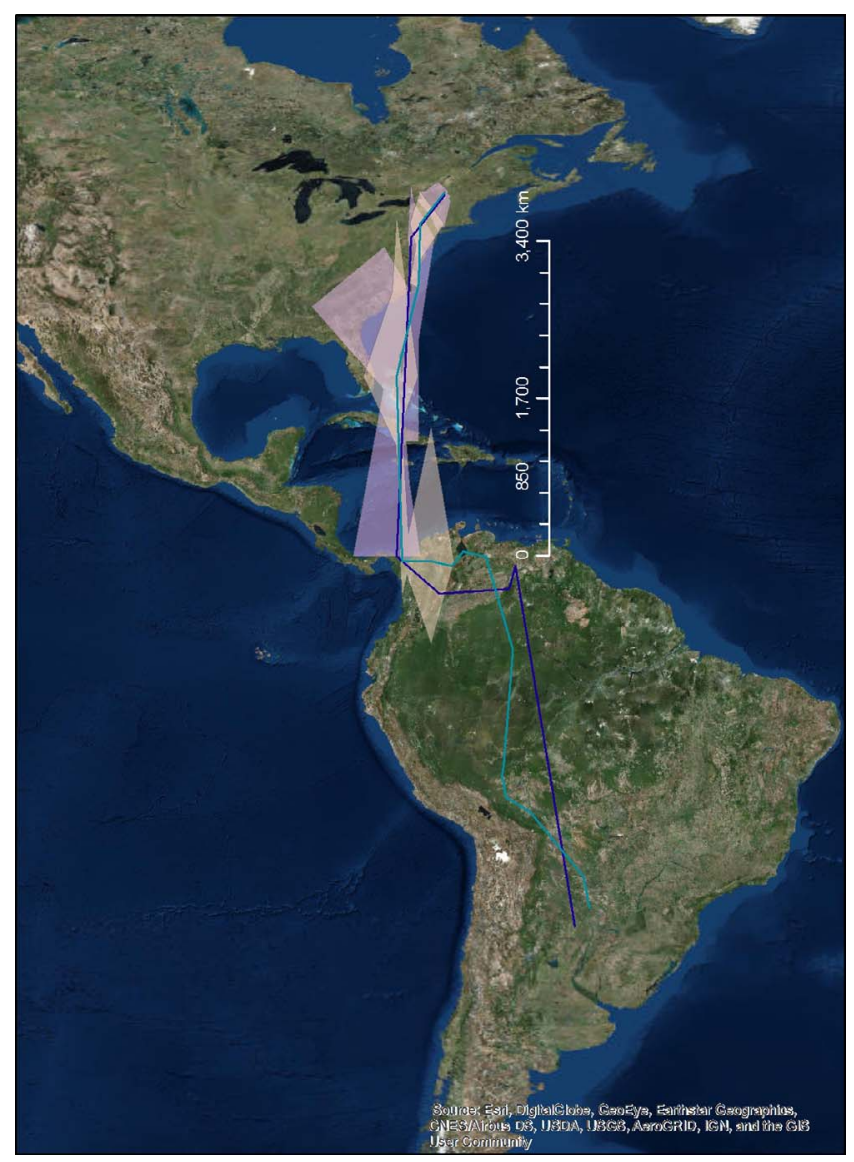

APPENDIX FIGURE 4. The fall migration route of 2 Bobolinks and associated error around this route modeled by FLightR. Error polygons (shaded regions) were created by overlaying twilight-specific $95 \%$ credible intervals during fall migration to South America. 